\title{
Insights into the bioavailability of oceanic dissolved Fe from phytoplankton uptake kinetics
}

\author{
Yeala Shaked $\mathbb{1}^{1,2} \cdot$ Kristen N. Buck $^{3} \cdot$ Travis Mellett $^{3} \cdot$ Maria. T. Maldonado $^{4}$
}

Received: 6 August 2019 / Revised: 12 January 2020 / Accepted: 21 January 2020 / Published online: 5 February 2020

(c) The Author(s) 2020. This article is published with open access

\begin{abstract}
Phytoplankton growth in large parts of the world ocean is limited by low availability of dissolved iron ( $\mathrm{dFe})$, restricting oceanic uptake of atmospheric $\mathrm{CO}_{2}$. The bioavailability of $\mathrm{dFe}$ in seawater is however difficult to appraise since it is bound by a variety of poorly characterized organic ligands. Here, we propose a new approach for evaluating seawater $\mathrm{dFe}$ bioavailability based on its uptake rate constant by Fe-limited cultured phytoplankton. We utilized seven phytoplankton species of diverse classes, sizes, and provenances to probe for $\mathrm{dFe}$ bioavailability in 12 seawater samples from several ocean basins and depths. All tested phytoplankton acquired organically bound $\mathrm{Fe}$ in any given sample at similar rates (after normalizing to cellular surface area), confirming that multiple, Fe-limited phytoplankton species can be used to probe dFe bioavailability in seawater. These phytoplankton-based uptake rate constants allowed us to compare water types, and obtain a grand average estimate of seawater $\mathrm{dFe}$ bioavailability. Among water types, $\mathrm{dFe}$ bioavailability varied by approximately four-fold, and did not clearly correlate with $\mathrm{Fe}$ concentrations or any of the measured Fe speciation parameters. Compared with well-studied Fe complexes, seawater $\mathrm{dFe}$ is more available than model siderophore $\mathrm{Fe}$, but less available than inorganic Fe. Exposure of seawater to sunlight, however, significantly enhanced $\mathrm{dFe}$ bioavailability. The rate constants established in this work, not only facilitate comparison between water types, but also allow calculation of Fe uptake rates by phytoplankton in the ocean based on measured dFe concentrations. The approach established and verified in this study, opens a new way for determining dFe bioavailability in samples across the ocean, and enables modeling of in situ Fe uptake rates by phytoplankton using dFe concentrations from GEOTRACES datasets.
\end{abstract}

\section{Introduction}

Iron $(\mathrm{Fe})$ exerts a strong influence on the biogeochemical cycles of carbon and other bioactive elements in the ocean, through control of phytoplankton growth [1-6]. To understand and model how Fe concentrations control

Supplementary information The online version of this article (https:// doi.org/10.1038/s41396-020-0597-3) contains supplementary material, which is available to authorized users.

Yeala Shaked

yeala.shaked@mail.huji.ac.il

1 The Fredy and Nadine Herrmann Institute of Earth Sciences, Hebrew University of Jerusalem, Jerusalem, Israel

2 Interuniversity Institute for Marine Sciences, Eilat, Israel

3 College of Marine Science, University of South Florida, Tampa, FL, USA

4 Earth, Ocean and Atmospheric Sciences Department, University of British Columbia, Vancouver, BC, Canada phytoplankton physiology and ecology, we must evaluate the bioavailability of $\mathrm{Fe}$ to phytoplankton. Building on the solid foundation laid during 40 years of extensive research on Fe availability to laboratory cultures [7-11], we set out to evaluate the bioavailability of natural dissolved $\mathrm{Fe}(\mathrm{dFe})$ from different oceanic locations and depths by examining phytoplankton uptake kinetics.

Our approach of conducting uptake assays to determine the bioavailability of $\mathrm{Fe}$ bound to uncharacterized organic ligands in the surface ocean draws from the seminal studies of Hudson and Morel [12, 13] and Sunda and Huntsman [14, 15], who reported that several Fe-limited eukaryotic phytoplankton species acquire dissolved inorganic $\mathrm{Fe}\left(\mathrm{Fe}^{\prime}\right)$ at identical rates, at a given $\mathrm{Fe}$ concentration, when accounting for their cellsurface area (S.A.). The consistency in S.A. that normalized $\mathrm{Fe}$ uptake rate probably reflects the number of $\mathrm{Fe}$ transporters on the cell surface, which is limited by the size of the transporters and the available membrane area allocated for $\mathrm{Fe}$ acquisition [12]. The similarity in S.A.-normalized Fe uptake rate among eukaryotic phytoplankton species suggests that $\mathrm{Fe}$ in aquatic environments exerted significant selective pressure 
on phytoplankton to evolve $\mathrm{Fe}$ uptake mechanisms that operate at the optimal efficiency permitted by fundamental biophysical and chemical constraints [13, 14].

These findings were recently extended to additional eukaryotic and prokaryotic phytoplankton species by Lis et al. [16], who invoked the use of $\mathrm{Fe}$ uptake rate constants $\left(\mathrm{k}_{\mathrm{in}}\right.$ in units of $\mathrm{L}$ cell ${ }^{-1} \mathrm{~d}^{-1}$ ) rather than uptake rates to compare phytoplankton data from uptake assays with different $\mathrm{Fe}$ concentrations $[\mathrm{Fe}]$, where $\mathrm{k}_{\mathrm{in}}=$ uptake rate/[Fe]. Examining $\mathrm{Fe}$ uptake rate constants $\left(\mathrm{k}_{\mathrm{in}}\right.$ of $\left.\mathrm{Fe}\right)$ of 25 different Fe-limited phytoplankton species, and accounting for their surface areas, they found a remarkable similarity among all species, implying that the bioavailability of $\mathrm{Fe}$ can be described with a single surface area-normalized uptake rate constant $\left(\mathrm{k}_{\mathrm{in}} / \mathrm{S}\right.$.A. of $\mathrm{Fe}^{\prime}$ ) [16]. Similarly, uptake of $\mathrm{Fe}$ from strong organic $\mathrm{Fe}$ complexes-such as the siderophore Ferrioxamine B (FeDFB) — by various Fe-limited phytoplankton species was found to converge into a common surface area-normalized $\mathrm{Fe}$ uptake rate constant for each organic Fe complex tested (e.g., $\mathrm{k}_{\mathrm{in}} / \mathrm{S}$.A. of FeDFB). Interestingly, the $\mathrm{k}_{\mathrm{in}} / \mathrm{S}$.A. of different organic Fe complexes varied by 1000 -fold, and the $\mathrm{k}_{\mathrm{in}} / \mathrm{S}$.A. of most complexes were much lower than those of inorganic Fe. These findings support previous data showing that inorganic $\mathrm{Fe}$ is more bioavailable than organically bound $\mathrm{Fe}$, and that organic $\mathrm{Fe}$ complexes differ in their bioavailability to phytoplankton $[9,11,17-19]$. Therefore, the bioavailability of different $\mathrm{Fe}$ complexes - either organically bound (FeL) or inorganic $\mathrm{Fe}\left(\mathrm{Fe}^{\prime}\right)$ — can be defined and ranked according to their respective $\mathrm{k}_{\mathrm{in}} / \mathrm{S}$.A. values. These surface area-normalized uptake rate constants $\left(k_{i n} /\right.$ S.A.), obtained with phylogenetically diverse Fe-limited phytoplankton species, are robust tools for assessing bioavailability of $\mathrm{Fe}$ complexes since they remain unchanged in cells experiencing different degrees of $\mathrm{Fe}$ limitation $[14,16]$. Yet, a significant drop in $\mathrm{k}_{\text {in }} / \mathrm{S}$.A. was observed for Fe-sufficient cells [16] where different $\mathrm{Fe}$ transport mechanisms likely operate (low vs. high affinity) $[11,20,21]$, and hence bioavailability of Fe complexes can be probed only with Fe-limited phytoplankton.

Here, we applied this approach to probe the bioavailability of $\mathrm{Fe}$ in seawater, where the vast majority of $\mathrm{dFe}$ is bound to a mixture of mostly uncharacterized organic ligands. Indeed, the speciation of $\mathrm{dFe}$ in seawater is typically determined by concentrations and stability constants of organic ligands, which are measured with electrochemical methods [22-24]. These measurements allow us to ascribe Fe-binding organic ligands $\left(\mathrm{L}_{i}\right)$ to a given ligand class $(i=1,2,3,4)$ based on their conditional stability constants $\left(K_{F e L_{1}, F e^{\prime}}^{c o n d}\right)$. The strongest ligands, those in the $\mathrm{L}_{1}$ ligand class, have the highest conditional stability constants $\left(\log K_{F e L_{1}, F e^{\prime}}^{c o n d}>12\right)$, while $\mathrm{L}_{2}$ ligands have $\log K_{\mathrm{FeL}_{2}, \mathrm{Fe}^{\prime}}^{\text {cond }}$ ranging between 11 and 12 [24]. Given that the nature of these $\mathrm{dFe}$-binding organic ligands in seawater is largely unknown, we suggest treating the entire pool of dFe as the substrate for uptake, and describe the average bioavailability of this pool with a single surface areanormalized $\mathrm{Fe}$ uptake constant $-\mathrm{k}_{\text {in-app }} / \mathrm{S}$.A. We added an apparent (i.e., "app") term to the uptake constant to indicate that it probably reflects a mixture of Fe complexes, unlike the $\mathrm{k}_{\mathrm{in}}$ that is drawn from a specific Fe complex [16].

Our study aimed at probing oceanic $\mathrm{dFe}$ bioavailability by using several cultured Fe-limited phytoplankton and seawater samples collected from a variety of oceanic regions and depths. dFe bioavailability in each seawater sample was assessed with a single kinetic term- $\mathrm{k}_{\text {in-app }} /$ S.A.- - established by multiple short-term $\mathrm{Fe}$ uptake experiments with different $\mathrm{Fe}$-limited cultures. We carefully tested and verified this novel methodology, and examined the effects of photochemistry and $\mathrm{Fe}$ speciation on $\mathrm{dFe}$ bioavailability in these natural seawater samples.

\section{Methods}

\section{Seawater sample collection}

Seawater samples from different ocean basins (Table 1) were collected following GEOTRACES protocols [25] using tracemetal clean rosette systems outfitted with either GO-Flo (General Oceanics) or x-Niskin samplers (Ocean Test Equipment). Samples were filtered through $0.2 \mu \mathrm{m}$ Acropak capsule filters and stored frozen $\left(-20^{\circ} \mathrm{C}\right)$ in trace-metal clean $500-\mathrm{mL}$ fluorinated high-density polyethylene (FPE) bottles (Nalgene) until analyzed for $\mathrm{Fe}$ speciation at the University of South Florida. The FPE bottles for $\mathrm{dFe}$ speciation were cleaned by soaking first in a $1 \%$ soap (Citranox; Fisher) bath for 1 week, followed by at least a month in a $25 \%$ hydrochloric acid $(\mathrm{HCl}$, trace-metal grade, Fisher); once clean, the bottles were rinsed and filled with Milli-Q $(>18.2 \mathrm{M} \Omega \cdot \mathrm{cm})$ until use [26]. Arctic seawater from Baffin Bay (BBA), Canadian Arctic Archipelago (CCA), and Beaufort Sea (BS) was collected as part of the Canadian GEOTRACES Arctic Program (legs 2 and 3, Aug-Sep 2015). North Pacific seawater (P16, P20 surface, and P20 deep) was collected in June 2017 from stations P16 and P20 during a Line-P cruise (GPpr07 GEOTRACES Process Study). Seawater from the Eastern Tropical South Pacific (EPZT surface, EPZT deep, and EPZT oxygen-depleted zone-ODZ) was collected as part of the US GEOTRACES program cruise GP16 (Eastern Pacific Zonal Transect) in late 2013. Seawater from the North Atlantic (GTNA, GEOTRACES North Atlantic) was collected as part of the US GEOTRACES program cruise GA03 (North Atlantic Zonal Transect) in 2011. Seawater from the eastern Gulf of Mexico (GOM) was collected aboard the R/V Weatherbird II using a surface towfish in June 2015. Seawater from the Southern Ocean (SO) was collected from the R/V/I/ B Nathanial B. Palmer using a trace-metal clean rosette system in September 2016 (cruise NBP 1608). 
Table 1 Description of the seawater samples analyzed in this study, including sampling location, depth of collection, iron concentration (dFe), and iron speciation results, including iron-binding organic ligand $\left(\mathrm{L}_{1}\right.$ and $\left.\mathrm{L}_{2}\right)$ concentrations and log-conditional stability constants (log $\mathrm{K}$ ).

\begin{tabular}{|c|c|c|c|c|c|c|c|c|c|c|c|c|c|}
\hline Sample description & & Ocean basin & Lat & Long & Depth & {$[\mathrm{dFe}]^{\mathrm{a}}$} & {$\left[\mathrm{L}_{1}\right]$} & $\begin{array}{l}\log K \\
\left(L_{1}\right)\end{array}$ & {$\left[\mathrm{L}_{2}\right]$} & $\begin{array}{l}\log K \\
\left(L_{2}\right)\end{array}$ & {$\left[\mathrm{Fe}^{\prime}\right]$} & $\alpha^{\prime b}$ & $\alpha^{\mathrm{c}}$ \\
\hline Full & Abbreviated & & ${ }^{\circ} \mathrm{N}$ & ${ }^{\circ} \mathrm{E}$ & $\mathrm{m}$ & $(\mathrm{nM})$ & $(\mathrm{nM})$ & & $(\mathrm{nM})$ & & $\mathrm{pM}$ & & \\
\hline Baffin Bay & $\mathrm{BBA}$ & Arctic & 71.4 & -68.6 & 37 & 1.56 & 1.83 & 12.46 & - & - & 2.0 & 779 & 5278 \\
\hline $\begin{array}{l}\text { Canadian Arctic } \\
\text { Archipelago }\end{array}$ & CAA & Arctic & 74.5 & -80.6 & 44 & 0.97 & 1.79 & 12.06 & - & - & 1.0 & 941 & 2055 \\
\hline Beaufort Sea & BS & Arctic & 75.8 & -129.2 & 10 & 0.74 & - & - & 1.74 & 11.67 & 1.6 & 468 & 81 \\
\hline North Pacific P16 & $\mathrm{P} 16$ & Pacific & 49.2 & -134.4 & 25 & 0.58 & - & - & 1.83 & 11.69 & 0.9 & 612 & 896 \\
\hline North Pacific P20 Surface & P20_Surf & Pacific & 49.3 & -138.4 & 25 & 0.95 & 1.35 & 12.30 & 1.82 & 11.28 & 0.8 & 1145 & 3040 \\
\hline North Pacific P20 Depth & P20_Deep & Pacific & 49.3 & -138.4 & 800 & 0.97 & - & - & 3.23 & 10.91 & 5.3 & 184 & 263 \\
\hline Southern Ocean & $\mathrm{SO}$ & Southern Ocean & -61.1 & -67.3 & 100 & 1.37 & 1.92 & 12.08 & - & - & 1.8 & 743 & 2308 \\
\hline Gulf of Mexico & GOM & Atlantic & 26.0 & -85.5 & 2 & 0.60 & - & - & 1.81 & 11.79 & 0.8 & 746 & 1116 \\
\hline Atlantic Zonal Transect & GTNA & Atlantic & 26.1 & -44.8 & 100 & 0.63 & 0.79 & 12.39 & 0.93 & 11.26 & 1.1 & 591 & 2108 \\
\hline $\begin{array}{l}\text { Equatorial Pacific Oxygen } \\
\text { Depleted Zone }\end{array}$ & EPZT_ODZ & Pacific & -12.0 & -77.7 & 20 & 1.67 & 1.48 & 12.57 & 2.73 & 11.08 & 5.5 & 302 & 5827 \\
\hline Equatorial Pacific Surface & EPZT_Surf & Pacific & -12.0 & -94.0 & 2,20 & 0.46 & 0.78 & 12.35 & 1.22 & 11.39 & 0.5 & 955 & 2046 \\
\hline Equatorial Pacific Depth & EPZT_Deep & Pacific & -12.0 & -89.0 & 3000 & 1.17 & - & - & 3.01 & 11.39 & 2.3 & 513 & 739 \\
\hline
\end{tabular}

Ligand classes $\left(\mathrm{L}_{1}, \mathrm{~L}_{2}\right)$ were defined by measured conditional stability constants; the notation of "-" was used for ligand classes not detected in the samples. Dissolved inorganic Fe $\left(\mathrm{Fe}^{\prime}\right)$ and complexation capacity of free ligands $\left(\alpha^{\prime}\right)$ and total ligands $(\alpha)$ were calculated from the speciation data.

${ }^{\mathrm{a}}$ Ambient dissolved $\mathrm{Fe}(\mathrm{dFe})$ plus $0.4 \mathrm{nM}{ }^{55} \mathrm{Fe}$.

${ }^{\mathrm{b}} \alpha^{\prime}=\sum\left[e L_{i}\right] \times K_{F e L_{i}, F e^{\prime}}^{c o n d}$

${ }^{\mathrm{c}} \alpha=\sum\left[L_{i}\right] \times K_{\mathrm{FeL}}^{\mathrm{cond}, F e^{\prime}}$

Table 2 Description of the phytoplankton species cultured in this study under iron-limited conditions in order to probe the bioavailability of dissolved iron $(\mathrm{dFe})$ in natural seawater.

\begin{tabular}{|c|c|c|c|c|c|c|c|c|}
\hline \multirow[t]{2}{*}{ Phylum } & \multicolumn{3}{|l|}{ Species } & \multirow[t]{2}{*}{ Environment } & \multicolumn{2}{|c|}{ Fe-limited cell size } & \multicolumn{2}{|c|}{ Fe-limited growth rate } \\
\hline & Full name & Abbreviated & Strain & & & $\begin{array}{l}\text { Diamete- } \\
\mathrm{r}(\mu \mathrm{m})\end{array}$ & $\begin{array}{l}\text { S.A. } \\
\left(\mu \mathrm{m}^{2}\right)\end{array}$ & $\mu\left(d^{-1}\right)$ \\
\hline \multicolumn{9}{|l|}{$\%$ from $\mu_{\max }$} \\
\hline Dinoflagellata & Prorocentrum micans & PM & CСMP 692 & Coastal & $\begin{array}{l}22-25(\mathrm{H}) \\
11-13(\mathrm{D})\end{array}$ & $\begin{array}{l}1000 \\
1300\end{array}$ & $0.24-0.28$ & $66-78 \%$ \\
\hline Bacillariophyta & Thalassiosira weissflogii & TW & CCMP 1047 & Coastal & $10.8-11.2$ & $364-392$ & $0.63-0.69$ & $75-82 \%$ \\
\hline Bacillariophyta & Thalassiosira oceanica & TO & CCMP 1003 & Open ocean & $4.9-5.2$ & $75-84$ & $0.83-0.85$ & $67-70 \%$ \\
\hline Bacillariophyta & Thalassiosira pseudonana & $\mathrm{TP}$ & NEPCC 58 & Open ocean & $4.7-5.2$ & $70-78$ & $0.73-0.75$ & $65-67 \%$ \\
\hline Haptophyta & $\begin{array}{l}\text { Chrysochromulina } \\
\text { polylepis }\end{array}$ & $\mathrm{CP}$ & NEPCC 242 & Coastal/ open & $3.9-4.1$ & $47-53$ & $0.33-0.39$ & $41-49 \%$ \\
\hline Haptophyta & Phaeocystis pouchetii & PP & NEPCC 225 & Open ocean & $3.9-4.3$ & $48-58$ & $0.50-0.55$ & $59-65 \%$ \\
\hline Chlorophyta & Micromonas sp. & Mic & CCMP 2709 & Open ocean & $1.4-2.3$ & $6-16$ & $0.33-0.39$ & $50-59 \%$ \\
\hline
\end{tabular}

"Environment" refers to the oceanic ecosystem where these species typically grow. Cells diameter was measured with a Coulter Counter and was converted to surface area (S.A.) assuming a spherical shape (except for Prorocentrum micans, where a prolate sphere equation was applied). A range of growth rates is reported for the cultures that were kept in exponential growth under Fe-limiting conditions for at least 25 generations prior to the uptake experiments.

\section{Phytoplankton choice, culturing, and growth monitoring}

Seven phytoplankton species from four classes were cultured in this study (Table 2). The species chosen represent dominant phytoplankton phyla in coastal- and open-ocean waters, and encompass a large size range. Cultures were obtained from the northeast Pacific Culture Collection (NEPCC, University of British Columbia, Vancouver, Canada) and the Center for Culture of Marine Phytoplankton (CCMP, Bigelow Laboratory, West Boothbay Harbor, ME, USA). Sterile, trace-metal-clean 
techniques were used throughout the experiments. All culture bottles and plasticware used to prepare the media were soaked in a dilute Extran detergent for $48 \mathrm{~h}$, rinsed with deionized water, soaked in $10 \%$ nitric acid for $48 \mathrm{~h}$, rinsed six times with ultrapure water $(18 \mathrm{M} \Omega \cdot \mathrm{cm}$; Milli-Q, Millipore), and finally microwave-sterilized before use. Cultures were grown in $28-\mathrm{mL}$ polycarbonate tubes at 19 $\pm 1{ }^{\circ} \mathrm{C}$ under a continuous saturating light level of 175 $\mu$ mol quanta $\mathrm{m}^{-2} \mathrm{~s}^{-1}$ as described in Maldonado et al. [20]. Briefly, growth media was based on station Papa seawater collected during a Line-P cruise and filtered (0.2 $\mu \mathrm{m}$, AcroPack) onboard according to GEOTRACES protocols. Station Papa seawater was enriched with filtersterilized $(0.2 \mu \mathrm{m}$, Acrodisc $)$ nitrate $\left(300 \mu \mathrm{mol} \mathrm{\textrm {L } ^ { - 1 }}\right.$ $\left.\mathrm{NO}_{3}{ }^{-}\right)$, phosphate $\left(10 \mu \mathrm{mol} \mathrm{L}{ }^{-1} \mathrm{PO}_{4}{ }^{3-}\right)$, and silicic acid $\left(100 \mu \mathrm{mol} \mathrm{L}{ }^{-1} \mathrm{H}_{4} \mathrm{SiO}_{4}\right)$ that were first passed through a chromatography column (Bio-Rad) containing Chelex ${ }^{\circledR}$ ion-exchange resin (Bio-Rad) to remove any trace metals ("chelexed"). Prior to use, this basal medium was microwave-sterilized and amended with vitamins (biotin, thiamine, and $\mathrm{B}_{12}$ ), and a mix of trace metals (without $\mathrm{Fe}$ ) buffered with $100 \mu \mathrm{mol} \mathrm{L}^{-1}$ EDTA (ethylene-diaminetetraacetic acid). Finally high $\mathrm{Fe}\left(1.37 \mu \mathrm{mol} \mathrm{L}^{-1} ; \mathrm{pFe} 19\right)$ and low $\mathrm{Fe}\left(12.5 \mathrm{nmol} \mathrm{L}^{-1}\right.$; pFe21) media were generated by adding $\mathrm{Fe}$ complexed by EDTA (1:1.5 Fe:EDTA ratio). Cultures were constantly maintained in the exponential phase by serial dilutions into fresh medium as needed, and growth rates were monitored daily by measuring in vivo chlorophyll $a$ fluorescence (Turner 10-AU Fluorometer). Cultures were first grown in high $\mathrm{Fe}$ and then gradually acclimated to low Fe. Specific growth rates $(\mu)$ were determined as per day $\left(\mathrm{d}^{-1}\right)$ from linear regressions of the natural $\log$ of in vivo fluorescence versus time during the exponential growth phase of acclimated cells, after confirming a proportional relationship between fluorescence and cell concentration. Cultures were considered acclimated when growth rates in successive transfers varied by less than $15 \%$ (typically $4-5$ transfers). Cell concentrations and diameters were measured using a Coulter Z2 Particle Count and Size Analyzer (Beckman Coulter Inc.). Cell-surface area and volume were calculated, assuming that the cells were spherical, for all cultures except Prorocentrum micans (PM), where a prolate sphere equation was applied. Coulter counter-based surface area estimates were refined and confirmed by light and epi-fluorescence microscopic observations.

\section{Short-term Fe uptake experiments}

The bioavailability of $\mathrm{dFe}$ in the different seawater samples was examined by an extensive series of short-term uptake assays with Fe-limited cultures using low, sub-nanomolar concentrations of the radiotracer ${ }^{55} \mathrm{Fe}$. The radioisotope was purchased from Perkin Elmer as an acidic ${ }^{55} \mathrm{FeCl}_{3}$ solution with a specific activity $47 \mathrm{mCi} \mathrm{mg} \mathrm{Fe}{ }^{-1}$. Additions of radioisotope into the assay consider the total amount of $\mathrm{Fe}$ in the stock (including non-radiolabeled $\mathrm{Fe}$ ), but for simplicity are noted as ${ }^{55} \mathrm{Fe}$ only. Contamination with non-radiolabeled $\mathrm{Fe}$ was minimized by following stringent trace-metal clean protocols and conducting all assays within a laminar flow hood. Concentrations of free organic ligands in all samples (Table 1) were higher than the added $0.4 \mathrm{nM}{ }^{55} \mathrm{Fe}$, enabling the radiotracer to be complexed by the ambient ligands. To allow enough time for equilibration between the radiotracer and the ambient organic ligands, samples were thawed and spiked with ${ }^{55} \mathrm{Fe}, 24 \mathrm{~h}$ prior to the uptake assays. ${ }^{55} \mathrm{Fe}$ loss to the bottle walls was prevented by pre-mixing the ${ }^{55} \mathrm{Fe}$ stock with a low EDTA concentration (1:1.2 Fe:EDTA ratio). The exchange of ${ }^{55} \mathrm{Fe}$ between the added ${ }^{55} \mathrm{FeEDTA}$ and the natural ligands in seawater was examined by Mellet et al. 2018, who found that a period of $24 \mathrm{~h}$ was sufficient for equilibration between FeEDTA and natural ligands [27]. Briefly, $0.2 \mathrm{nM}$ FeEDTA (1:1.2 Fe:EDTA ratio) was added to NE Pacific seawater sample from a depth of $20 \mathrm{~m}$, and the speciation of $\mathrm{Fe}$ was characterized prior to and $24 \mathrm{~h}$ after FeEDTA addition by voltammetry (see "Methods"). The addition of FeEDTA resulted in a drop of $\sim 0.4 \mathrm{nM}$ in the measured free ligand concentrations [L], suggesting that $\mathrm{Fe}$ dissociated from the FeEDTA complex and was complexed by the free natural ligands (Supplementary Fig. S2). For the short-term Fe uptake assays, each ${ }^{55} \mathrm{Fe}$ spiked water type was split to $80-150 \mathrm{~mL}$ aliquots and placed in clean polycarbonate bottles. Mid-exponential Fe-limited cultures were gently filtered on acid-cleaned polycarbonate membrane filters of appropriate pore size and carefully washed with chelexed seawater to remove left-over growth media, while keeping the membranes wet at all times. Cells were then resuspended in the ${ }^{55} \mathrm{Fe}$ spiked aliquots and incubated at room temperature (20-22 $\left.{ }^{\circ} \mathrm{C}\right)$ under dim laboratory light for 4 to $6 \mathrm{~h}$. Every 1-2 $\mathrm{h}$ duplicate subsamples were withdrawn and filtered onto polycarbonate membranes and rinsed with $0.2-\mu \mathrm{m}$ filtered-Ti (III)EDTA-citrate reagent to remove extracellularly absorbed Fe [28]. The ${ }^{55} \mathrm{Fe}$ activity accumulated by the cells and in the tested solution was measured in a scintillation counter (Beckman-Coulter LS 6500; Beckman Counter Inc.) using Ecolite + scintillation cocktail (Fisher). Cell densities in the experiments were similar or slightly more concentrated than those in the original exponential cultures, ranging between $\sim 3-5 \times 10^{3}$ cells $\mathrm{mL}^{-1}$ in the largest species $\mathrm{PM}$ and $1-2 \times$ $10^{6}$ cells $\mathrm{mL}^{-1}$ in the smallest species Micromonas $s p$. (Supplementary Table S2). Cell concentrations and diameters in each bottle were measured during the assay using a Coulter Counter (Coulter Z2 Particle Count and Size Analyzer). Fe uptake rates $\left(\mathrm{mol} \mathrm{Fe}\right.$ cell $\left.{ }^{-1} \mathrm{~d}^{-1}\right)$ were calculated from the linear regression of the accumulated cellular $\mathrm{Fe}$ as a function 
of incubation time, considering the ambient $\mathrm{dFe}$ concentrations. Fe uptake by killed cells was negligible and so was the ${ }^{55} \mathrm{Fe}$ loss to the bottle walls (total activity remained unchanged throughout the experiment). Due to limited sample volume, not all experiments were run in duplicates. A few uptake assays were conducted outdoors to examine the effect of sunlight on $\mathrm{dFe}$ availability, using UV transparent acidcleaned 1-L Cubitainers (Fisher). To minimize the exposure time of the cells to the strong natural sunlight $(\sim 1000 \mu \mathrm{mol}$ quanta $\mathrm{m}^{-2} \mathrm{~s}^{-1}$ ), the seawater (without cells) was first exposed to sunlight for $1-2 \mathrm{~h}$. Washed cells were then quickly suspended in these pre-exposed samples and placed outdoors (but avoiding direct sunlight) and sub-sampled every 30-45 min for up to $1-2 \mathrm{~h}$. Parallel outdoors dark controls were performed and compared with the sun-exposed rates, to account for container and temperature effects.

\section{Total dissolved Fe and Fe speciation}

Dissolved Fe and Fe speciation data from the GEOTRACES samples (EPZT and GTNA) were previously published along with the methods used [22, 29]. For the remaining samples, an aliquot of seawater was poured into an acid clean $125 \mathrm{~mL}$ FPE bottle and acidified to $\mathrm{pH} 1.8$ (0.024 M Optima grade $\mathrm{HCl}$, Fisher). Dissolved $\mathrm{Fe}$ in the acidified sample was preconcentrated on a Nobias $1 \mathrm{~A}$ resin using the commercially available seaFAST (ESI) system, which facilitates preconcentration of trace metals from seawater samples into $1 \mathrm{~N}$ quartz-distilled nitric acid eluent. The eluent was then measured on a Thermo Scientific Element XR inductively coupled plasma mass spectrometer via method of standard addition; standard curves constructed in low metal and GEOTRACES reference samples were also processed on the seaFAST system to verify results. Fe speciation in the remaining unacidified seawater was determined using competitive ligand exchange-adsorptive cathodic stripping voltammetry (CLE-AdCSV; [29]). Briefly, fifteen $10 \mathrm{~mL}$ aliquots of the samples were buffered to $\mathrm{pH} 8.5$ with a borateammonium buffer and titrated with thirteen additions of $\mathrm{dFe}$ (0.1-10 nM, with two blanks). Following overnight equilibration of the Fe additions, the same aliquots were spiked with $25 \mu \mathrm{M}$ salicylaldoxime as a competing ligand, allowed to equilibrate again for at least $1 \mathrm{~h}$, and the resulting concentration of $\mathrm{Fe}$ bound to salicylaldoxime was measured by AdCSV on a BASi hanging mercury drop electrode. The titration data generated from this approach was then interpreted using the measured $\mathrm{dFe}$ concentrations in the freely available software program ProMCC [30] to obtain Febinding ligand concentrations, their stability constants and the 95\% confidence interval of each result. Titrations were modeled for one- and two-ligand classes with the selection of a model based on the same criteria used for GEOTRACES data sets, following best practices from intercomparisons of complexometric titration data [31], and using the visualization of results provided in ProMCC to determine the best fit to the titration data. Information on speciation data, calculations and errors appear in Supplementary Table S1.

\section{Data analysis and statistics}

Iron uptake rates were converted to per cell uptake rates constants $\left(\mathrm{k}_{\mathrm{in} \text {-app }}\right)$ based on the measured $\mathrm{dFe}$ in the sample (ambient + added ${ }^{55} \mathrm{Fe}$ ) and cell numbers, and were normalized to the cell-surface area, yielding the measure of $\mathrm{dFe}$ availability $-\mathrm{k}_{\mathrm{in} \text {-app }} / \mathrm{S}$.A. One-way repeated-measures analysis of variance was performed to test whether the average $\mathrm{k}_{\mathrm{in}-}$ App $/$ S.A. was indeed significantly different among seawater samples. Pearson correlations between the average $\mathrm{k}_{\text {in-app }} / \mathrm{S}$. A. values for each seawater sample and the $\mathrm{Fe}$ speciation parameters we determined were performed to explore the link between $\mathrm{Fe}$ speciation and $\mathrm{dFe}$ bioavailability.

\section{Results}

We evaluated dFe bioavailability in 12 water samples from different locations and depths (Table 1; Supplementary Table S1) by conducting $~ 85$ short-term Fe uptake experiments with Fe-limited cultures of 7 different phytoplankton strains varying in size, taxa, and isolation site (Table 2). From these measured $\mathrm{Fe}$ uptake rates, we calculated the $\mathrm{dFe}$ uptake rate constant for each experiment, for a specific phytoplankton species and seawater (SW) sample:

$$
\begin{aligned}
\mathrm{k}_{\text {in }- \text { app }}\left(\mathrm{L} \mathrm{cell}^{-1} \mathrm{~d}^{-1}\right)= & \text { uptake rate }(\text { mol Fe cell } \\
& / \mathrm{SW} \text { dFe concentration }\left(\mathrm{mol} \mathrm{Fe} \mathrm{L}^{-1}\right)
\end{aligned}
$$

These phytoplankton- and seawater-specific $\mathrm{k}_{\text {in-app }}$ values were then normalized to their respective cell S.A. to derive our $\mathrm{dFe}$ bioavailability proxy:

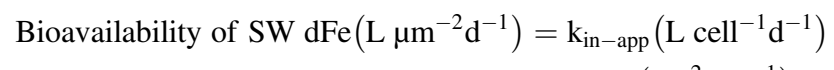

$$
\text { / S.A. }\left(\mu \mathrm{m}^{2} \mathrm{cell}^{-1}\right)
$$

\section{Establishing surface area-normalized Fe uptake rate constant- $k_{\text {in-app }} /$ S.A. - as a proxy of $\mathrm{dFe}$ bioavailability in natural seawater samples}

Having proposed a novel methodology for probing $\mathrm{dFe}$ bioavailability in natural waters, we first present raw data from a single seawater sample (Baffin Bay) to discuss our experimental design and interpretation of results. The 

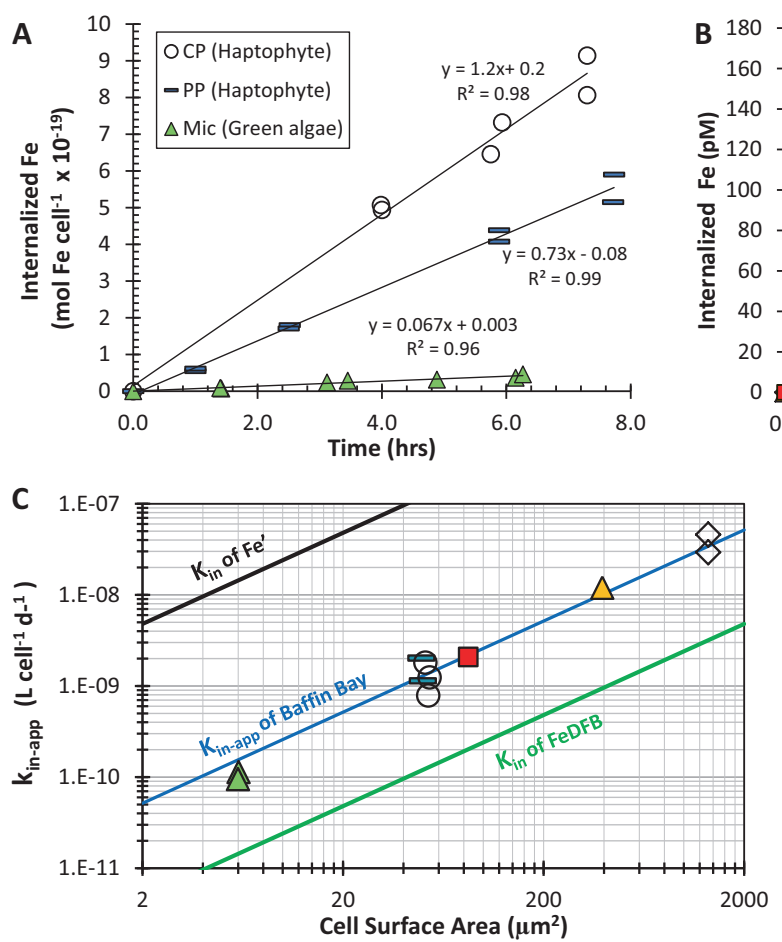
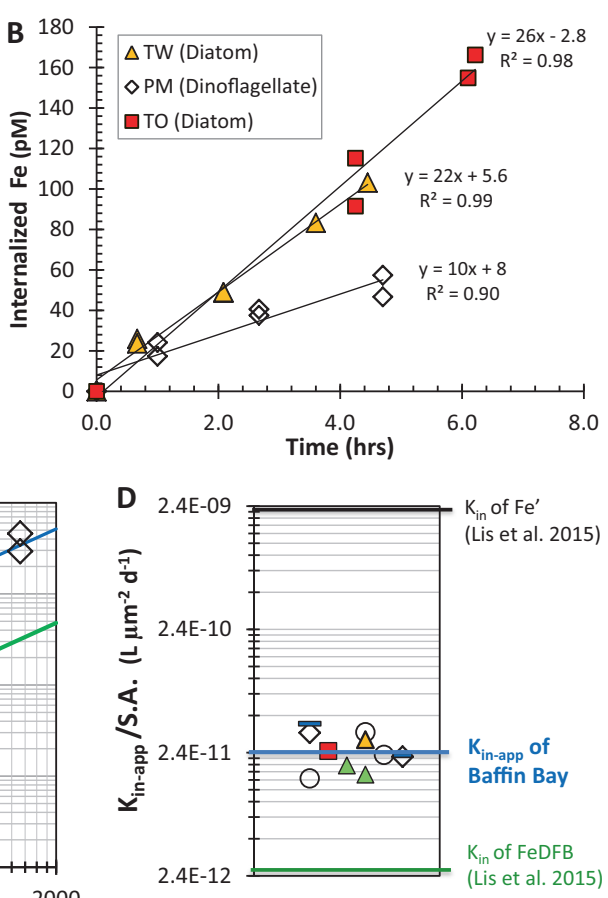

Fig. 1 Evaluation of the bioavailability of dissolved iron (dFe) in water from Baffin Bay in the Arctic. a, b Dissolved Fe uptake by Felimited phytoplankton species measured under stringent trace-metal clean protocols and internalized $\mathrm{Fe}$ plotted per cell (a) or as total internalized $\mathrm{Fe}$ (b). c, d Calculated Fe uptake rate constants for Baffin Bay water- $\mathrm{k}_{\text {in-app }}$ - the measure of $\mathrm{dFe}$ bioavailability as probed by Fe-limited phytoplankton species. Plotting $\mathrm{k}_{\text {in-app }}$ versus cellular surface area (S.A.) in a log-log plot yielded a single line (c), implying that all phytoplankton probe $\mathrm{dFe}$ bioavailability similarly when normalized to surface area (S.A.). Hence, a single kinetic term, $\mathrm{k}_{\text {in-app }} / \mathrm{S}$.A., can describe the $\mathrm{dFe}$ bioavailability in these waters (d). The bioavailability of $\mathrm{dFe}$ in Baffin Bay is intermediate between that of inorganic $\mathrm{Fe}\left(\mathrm{Fe}^{\prime}\right)$ and that of $\mathrm{Fe}$ bound to the strong siderophore desferrioxamine $\mathrm{B}$ (FeDFB), determined previously. Each phytoplankton strain is labeled in a unique symbol and color that is consistent across all panels.

$1.1-2.4 \times 10^{-7} \mathrm{~s}^{-1}$ [calculated from $K_{F e L_{i} F e^{\prime}}^{c o n d}=k_{f}^{\prime} / k_{d}^{\prime}$, where $\log K_{F e L_{1}, F e^{\prime}}^{c o n d}=12.46$ and $\left.k_{f}^{\prime}=3.2-6.9 \times 10^{5} \mathrm{M}^{-1} \mathrm{~s}^{-1}\right]$. Then, using these dissociation rate constants and the measured $[\mathrm{dFe}]$, we estimated the maximum supply of $\mathrm{Fe}^{\prime}$ to the cell surface for biological uptake; which in the case of Baffin Bay it was 1.3 pmol $\mathrm{Fe} \mathrm{L}^{-1} \mathrm{~h}^{-1}$ (Supplementary Table S3). This supply rate of $\mathrm{Fe}^{\prime}$ due to dissociation of $\mathrm{Fe}$ from organic $\mathrm{Fe}$ complexes (FeL) is significantly slower than the Fe uptake rates measured under very dim light (ranged from 7 to 32 pmol Fe $\mathrm{L}^{-1} \mathrm{~h}^{-1}$; Fig. 1b, Supplementary Table S2), implying that the cells were indeed accessing $\mathrm{Fe}$ from the organic $\mathrm{Fe}$ pool. Moreover, the $\mathrm{Fe}^{\prime}$ concentration initially present in Baffin Bay seawater (2 pmol $\mathrm{L}^{-1}$, Table 1) makes a negligible contribution to the 48-270 pmol L ${ }^{-1} \mathrm{Fe}$ internalized by the cells throughout the experiments (Fig. 1b; Supplementary Table S2). Similar findings were determined for all water types, except for one (Supplementary Tables S2-S4). Hence, we deduced that phytoplankton were indeed accessing $\mathrm{Fe}$ from organic complexes in the dissolved $\mathrm{Fe}$ pool, and thus the $\mathrm{k}_{\text {in-app }}$ should be calculated by dividing $\mathrm{Fe}$ internalization rates by concentration of $\mathrm{dFe}$, most of which $(>99 \%)$ is organically bound [24]. Note that our kinetic-based account of $\mathrm{Fe}$ 
uptake from $\mathrm{Fe}$ - organic ligand complexes does not specify or confine the transport mechanism at play. The reported mechanisms include reductive release of $\mathrm{Fe}(\mathrm{II})$ from the $\mathrm{Fe}-$ organic ligand complex [11, 17-19, 33], ternary complex formation and possible transfer of Fe from the organic to cell-surface ligand $[34,35]$, and internalization of the whole complex [36, 37], any of which may act simultaneously or separately.

Another important criterion for calculating $\mathrm{k}_{\mathrm{in}-\mathrm{app}}$ is that the rate of Fe uptake has to remain constant for the duration of the experiments (i.e., linear regression between internalized $\mathrm{Fe}$ and time). Indeed, the vast majority of the $\mathrm{Fe}$ uptake rates were linear $\left(\mathrm{R}^{2}>0.85\right)$ and had an intercept near the origin (e.g., Fig. 1a, b). In a few experiments $(<10 \%)$, we observed slower $\mathrm{Fe}$ internalization in the last time point, which was then excluded from the calculated rates of $\mathrm{Fe}$ uptake. For uptake to remain linear over the course of the experiment it is important to ensure that the overall $\mathrm{Fe}$ concentration acquired by the cells does not approach the total available Fe pool; this was accomplished using low cell densities in the experiments (Supplementary Tables S2, S4). The internalized Fe at the end of our uptake assays with the different water samples ranged from 2 to $270 \mathrm{pM}$ (Supplementary Tables S2, S4), and at most, accounted for $22 \%$ of the total dissolved $\mathrm{Fe}$ concentration.

Next, we examined if all tested phytoplankton species equally probe the bioavailability of $\mathrm{dFe}$ in a single water sample by plotting $\mathrm{k}_{\mathrm{in}-\mathrm{app}}$ against cell S.A., or by normalizing $\mathrm{k}_{\mathrm{in}-\mathrm{app}}$ to S.A. For Baffin Bay water, all $11 \mathrm{k}_{\mathrm{in-app}}$ values fall on a single line when plotted against S.A. (Fig. 1c) and can thus be normalized to their respective cellular S.A. to yield an average $\mathrm{k}_{\text {in-app }} / \mathrm{S}$.A. of $2.6 \times 10^{-11} \pm 8.5 \times 10^{-12} \mathrm{~L} \mathrm{\mu m}^{-2} \mathrm{~d}^{-1}$ (Fig. 1d; Supplementary Table S2). This surface areanormalized $\mathrm{k}_{\mathrm{in}-\mathrm{app}}$ describes the average bioavailability of the dissolved $\mathrm{Fe}$ in Baffin Bay seawater, and it fits within the "bioavailability envelope" of Lis et al. [16] (black and green lines in Fig. 1c, d).

\section{Evaluating dFe bioavailability in different seawater samples}

To evaluate $\mathrm{dFe}$ bioavailability in a variety of seawater samples, in addition to Baffin Bay, we present the dissolved Fe bioavailability proxy $-\mathrm{k}_{\text {in-app }} / \mathrm{S}$.A. - for all 12 water types in two formats: the value for individual experiments for each seawater sample and phytoplankton (Fig. 2a); and the average dFe bioavailability value for each water type (Fig. $2 b$ ). We also present all $\mathrm{k}_{\text {in-app }} / \mathrm{S}$.A. values in a supplementary table organized according to the phytoplankton species with which they were probed (Supplementary Table S5). In the individual experiments (Fig. 2a), it is evident that in some water types, all $\mathrm{k}_{\text {in-app }} /$ S.A. values obtained by different phytoplankton species
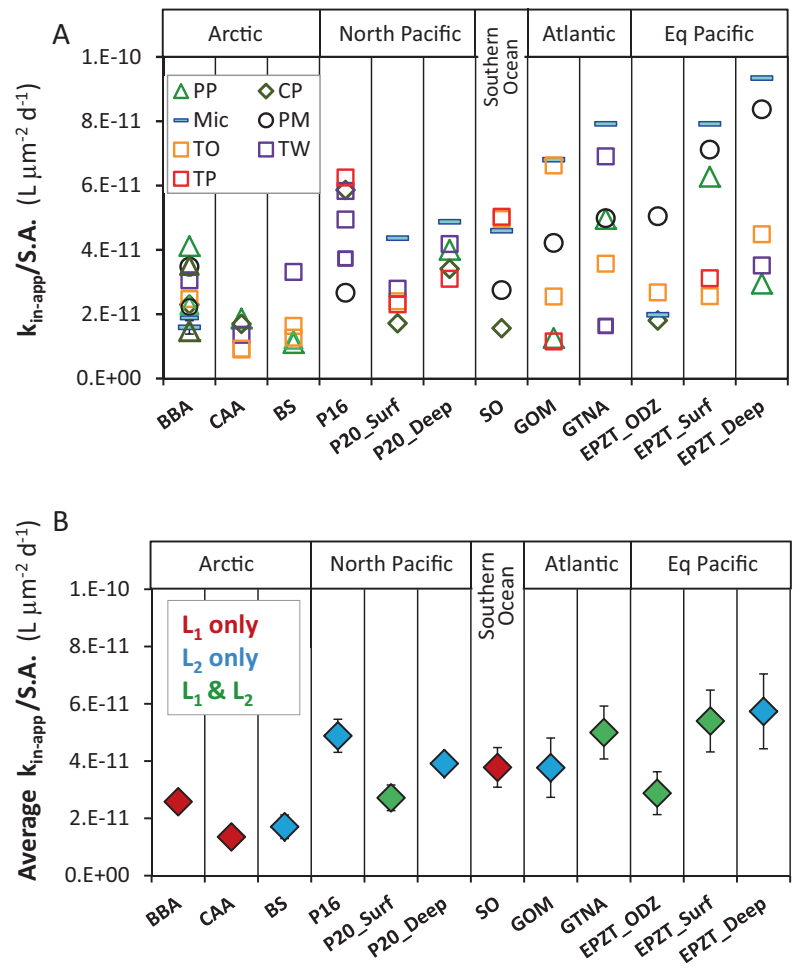

Fig. 2 Bioavailability of dissolved iron (dFe) in the 12 seawater types probed with seven iron-limited phytoplankton species under dim laboratory light. a Individual $\mathrm{dFe}$ bioavailability proxies $\left(\mathrm{k}_{\mathrm{in}-\mathrm{app}}\right)$ S.A.) in all tested water types (abbreviated on the $x$ axis), derived from Fe uptake rates of various Fe-limited phytoplankton (abbreviated in the legend). b Average dFe bioavailability (average $\mathrm{k}_{\mathrm{in}-\mathrm{app}} / \mathrm{S}$.A.) of all phytoplankton species as a function of water types, colored according to the classes of ligands present in each sample. Error bars are 1 standard deviation of the average. Phytoplankton species: Prorocentrum micans (PM), Thalassiosira weissflogii (TW), Thalassiosira oceanica (TO), Thalassiosira pseudonana (TP), Chrysochromulina polylepis (CP), Phaeocystis pouchetii (PP), and Micromonas sp. (MIC). Seawater samples: Arctic-Baffin Bay (BBA), Canadian Arctic Archipelago (CCA), Beaufort Sea (BS); North Pacific-Line-P stations-P16, P20 surface (P20_Surf), P20 depth (P20_Deep); Southern Ocean (SO); Atlantic_-Gulf of Mexico (GOM), GEOTRACES GA03 Atlantic Zonal Transect (GTNA); Equatorial Pacific-GEOTRACES GP16 Oxygen Depleted Zone (EPZT_ODZ), surface (EPZT_Surf), and depth (EPZT_Deep).

agree well with each other (8-14\% standard error), while in other samples $\mathrm{k}_{\mathrm{in} \text {-app }} / \mathrm{S}$.A. values are more scattered (18-27\% standard error). In some water types, Micromonas Sp. (Mic) and Prorocentrum micans (PM), yield the highest $\mathrm{k}_{\mathrm{in}-\mathrm{app}} / \mathrm{S}$.A., but this trend is reversed in other samples where Thalassiosira weissflogii (TW), Thalassiosira pseudonana (TP) and Phaeocystis pouchetii (PP) yield maximum values (Fig. 2a). Comparison of $\mathrm{k}_{\text {in-app }} / \mathrm{S}$.A. values from all water types across phytoplankton species (Supplementary Table S5), did not show any statistical differences among them. The lack of systematic differences in the dFe bioavailability parameter among phytoplankton species for a single seawater 
sample (Fig. 2a; Supplementary Table S5) suggests that the surface area-normalized $\mathrm{Fe}$ uptake constants of eukaryotic phytoplankton are similar, in line with previous studies $[11,16,38]$. This lack of systematic differences in $\mathrm{k}_{\mathrm{in} \text {-app }} / \mathrm{S}$.A. among tested phytoplankton strains does not necessarily imply that they all use similar uptake mechanisms, rather it indicates that their uptake mechanisms operate at the optimum efficiency permitted by fundamental physical, chemical or biochemical factors $[13,14]$. These findings suggest that multiple or any Felimited eukaryotic phytoplankton species can be used to probe $\mathrm{dFe}$ bioavailability in a water sample, and that the grand average $\mathrm{Fe}$ bioavailability value derived from a series of experiments with a single or several different phytoplankton species can be used to estimate the $\mathrm{dFe}$ bioavailability in that water sample. In future experiments employing this methodology, we recommend the use of phytoplankton with rigid cell walls and simple shape, such as centric diatoms, to ease experimental manipulations and calculations.

Moving from individual experiments (Fig. 2a) to average values (Fig. 2b), we performed one-way repeatedmeasures analysis of variance to test whether the average bioavailability of $\mathrm{dFe}$ was indeed significantly different among seawater samples. This analysis revealed that $\mathrm{dFe}$ bioavailability proxy $\left(\mathrm{k}_{\text {in-app }} / \mathrm{S}\right.$.A.) was significantly different among seawater samples $(p<0.01)$. The bioavailability of $\mathrm{dFe}$ among water types differs by $\sim$ four-fold, from the least bioavailable $\mathrm{dFe}$ in the Canadian Arctic Archipelago (CAA) to the most bioavailable $\mathrm{dFe}$ in the Equatorial Pacific Deep (EPZT_Deep; Fig. 2b). All three Arctic samples had relatively low dFe bioavailability, whereas some of the Equatorial and North Pacific samples had relatively high dFe availability. While seawater temperature and irradiance will affect $\mathrm{dFe}$ bioavailability in surface oceanic waters, in our laboratory experiments these variables were constant. Hence, the differences in dFe bioavailability reported here likely reflect differences in the chemical speciation of $\mathrm{Fe}$ in seawater. To explore the link between $\mathrm{Fe}$ speciation and $\mathrm{dFe}$ bioavailability, we performed Pearson correlations between the average $\mathrm{k}_{\text {in-app }} / \mathrm{S}$.A. values for each seawater sample and the $\mathrm{Fe}$ speciation parameters we determined, and are present in Table 1 and Supplementary Table S1. These include: Fe concentrations ([dFe] and $\left.\left[\mathrm{Fe}^{\prime}\right]\right)$, ligands concentrations ([L $\left.\mathrm{L}_{1}\right],\left[\mathrm{L}_{2}\right],\left[\mathrm{L}_{\text {total }}\right]$ (i.e. sum of both ligands), and [eL] (i.e. excess ligands not bound by $\mathrm{Fe}$ )) and complexation capacity of total ligands $(\alpha)$ and free ligands $\left(\alpha^{\prime}\right)$. The statistical analysis did not reveal any significant correlations $(p>0.05)$. In addition, visual examination of samples with different ligand types ( $\mathrm{L}_{1}$ or $\mathrm{L}_{2}$ only, or both), did not reveal consistent trends between $\mathrm{k}_{\mathrm{in} \text {-app }} / \mathrm{S}$.A. and $[\mathrm{dFe}]$, calculated FeL dissociation rate, complexation capacity of the free Fe-binding ligands in seawater $\left(\alpha^{\prime}\right)$, or excess ligands [eL] (Supplementary Fig. S1).

\section{Effect of photochemistry on dFe bioavailability}

All laboratory experiments were conducted under room-dim lights, not inducing photochemical production of $\mathrm{Fe}^{\prime}$ from organically bound $\mathrm{Fe}$. In the upper ocean, light and temperature influence the speciation of $\mathrm{dFe}$ and are thus likely to affect $\mathrm{dFe}$ bioavailability [36]. To examine the effect of photochemistry on our measured $\mathrm{dFe}$ bioavailability, we conducted a limited set of outdoor uptake experiments with three species of diatoms and six water types. In all the experiments, exposure to sunlight significantly increased the $\mathrm{dFe}$ bioavailability, with an average increase of six-fold in $\mathrm{k}_{\text {in-app }} / \mathrm{S}$.A. relative to the outdoor, dark controls (Fig. 3, sunlight/dark ratio ranging from 1 to 13 ).

In order to compare our experiments with published in situ experiments, we converted the $\mathrm{Fe}$ uptake rates reported in these studies to $\mathrm{k}_{\text {in-app }} / \mathrm{S}$.A. (Supplementary Table S6). In the Southern Ocean [18] and the California upwelling system [27], sunlight resulted in a 3- to 27-fold increase in $\mathrm{dFe}$ availability to natural phytoplankton, similar to the light enhancement in our experiments (1-13-fold, Fig. 3). In addition to documenting a positive effect of photochemistry on natural $\mathrm{dFe}$ availability, our outdoor experiments yielded $\mathrm{k}_{\mathrm{in}-\mathrm{app}} / \mathrm{S}$.A. values that agree well with other sunlight-exposed experiments [33, 37] (Supplementary Table S6), suggesting that our $\mathrm{dFe}$ bioavailability estimates can be generalized and implemented in models. Our findings are in agreement with previous studies documenting that in situ Fe ligands are photolabile, implying that photochemistry in surface waters may play a significant role in Fe acquisition from the dissolved organic $\mathrm{Fe}$ pool by oceanic planktons $[18,27]$.

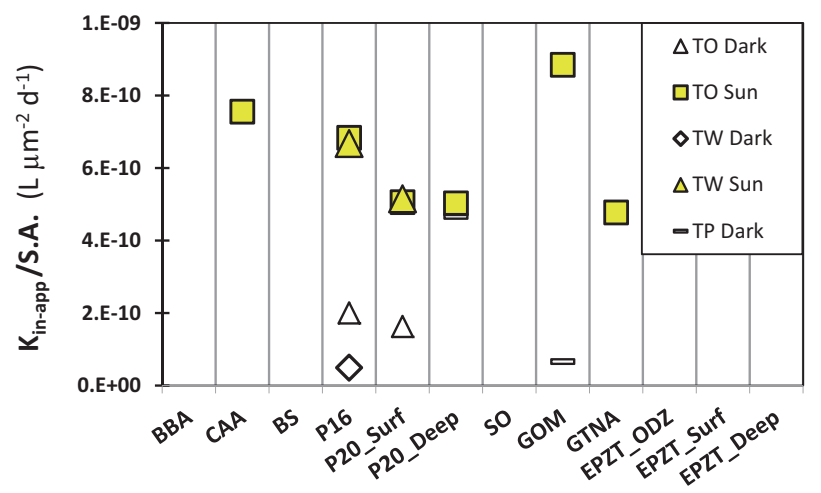

Fig. 3 Effect of photochemistry on bioavailability of dissolved iron $(\mathrm{dFe})$ in selected seawater types as probed with iron-limited diatoms during outdoor incubations. Diatoms species: TW, Thalassiosira weissflogii; TO Thalassiosira oceanica; TP, Thalassiosira pseudonana. Illuminated samples are noted as Sun, while covered samples are noted as Dark. See Table 1 for seawater type descriptions. 


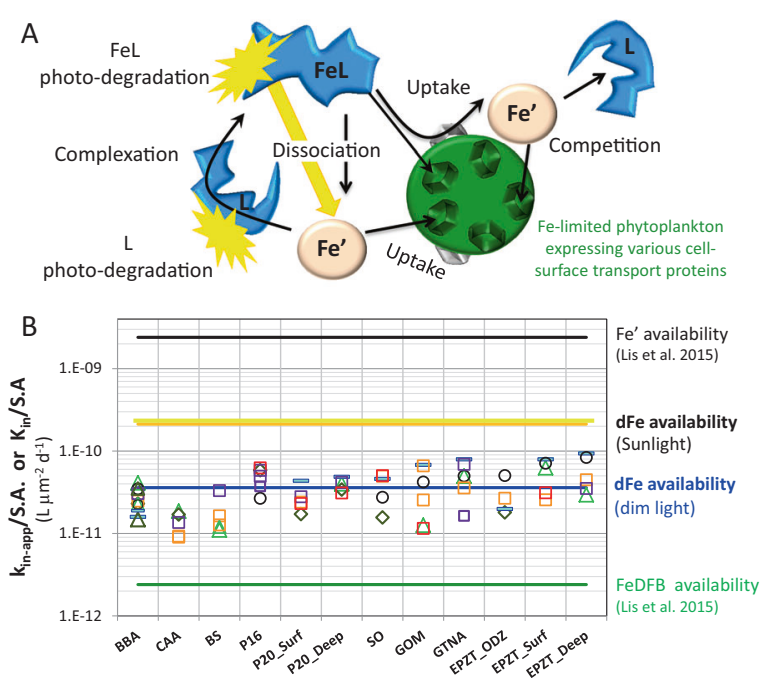

Fig. 4 Summary and synthesis. a Schematic representation of the major reactions at play, which govern the rate of uptake of iron $(\mathrm{Fe})$ from inorganic $\left(\mathrm{Fe}^{\prime}\right)$ and organic $(\mathrm{FeL})$ complexes by Fe-limited phytoplankton, and subsequently determine the dFe bioavailability proxy $-\mathrm{k}_{\mathrm{in}-\mathrm{app}} / \mathrm{S}$.A. b Summary of all data evaluating $\mathrm{dFe}$ bioavailability across all water types from this study in dim laboratory light and in outdoor full light, plotted within the framework of the bioavailability envelope of [16]. Symbols represent individual phytoplankton strains as in Fig. 2a. See Table 1 for seawater type descriptions.

\section{Discussion}

To assist synthesis, we provide a schematic outline of the major reactions at play that govern the rate of uptake by Felimited phytoplankton, and subsequently determine the $\mathrm{dFe}$ bioavailability proxy $-\mathrm{k}_{\text {in-app }} / \mathrm{S}$.A. (Fig. 4a). These include acquisition of Fe' and FeL via different pathways, dark dissociation of organically complexed Fe (FeL), and competition for $\mathrm{Fe}^{\prime}$ between free organic ligands (L) in seawater and cellsurface transporters/proteins. Photochemistry strongly enhances $\mathrm{FeL}$ dissociation, generating highly available $\mathrm{Fe}^{\prime}$, and photodegrading Fe-binding ligands, possibly decreasing $\mathrm{Fe}^{\prime}$ complexation and competition with the cell transporters (Fig. 4a). We will further explore these processes in an oceanographic context in the next paragraphs.

First, we discuss our experimental data within the context of the "bioavailability envelope" proposed by Lis et al. [16]. So far, we have highlighted a $\sim$ four-fold difference in $\mathrm{dFe}$ bioavailability among water types (Fig. 2). Nonetheless, considering that Fe bioavailability changes by 3 orders of magnitude between inorganic $\mathrm{Fe}\left(\mathrm{Fe}^{\prime}\right)$ and $\mathrm{Fe}$ bound to very strong siderophores like FeDFB (green and black lines in Fig. 4b), the bioavailability of $\mathrm{dFe}$ in the different water samples is, in fact, surprisingly similar. We can thus average the data from all of our experiments (blue line in Fig. 4b), and compare this grand average $\mathrm{dFe}$ bioavailability of oceanic seawater with that of specific Fe-binding ligands. The average $\mathrm{k}_{\mathrm{in}-\mathrm{app}} / \mathrm{S}$.A. of all indoor experiments is $3.6 \pm 0.25 \times 10^{-11} \mathrm{~L} \mathrm{\mu m}^{-2} \mathrm{~d}^{-1}$, and it falls within the lower range of the "bioavailability envelope", closer to the bioavailability of Fe bound to model siderophores such as FeDFB rather than to $\mathrm{Fe}^{\prime}$.

This average $\mathrm{dFe}$ bioavailability ( $\mathrm{k}_{\mathrm{in}-\mathrm{app}} / \mathrm{S}$.A.) is 15 -fold higher than that of FeDFB $\left(2.4 \times 10^{-12} \mathrm{~L} \mathrm{\mu m}^{-2} \mathrm{~d}^{-1}\right)$. In samples containing only $\mathrm{L}_{1}$ ligands, the elevated $\mathrm{dFe}$ bioavailability is consistent with their lower conditional stability constants $\left(\log K_{\mathrm{FeL}_{i}, F e^{\prime}}^{\mathrm{cond}}=12.1-12.5\right.$, Table 1) compared with DFB (log $K_{F e D F B, F e^{\prime}}^{c o n d}>13$; ref. [39]), and likely indicates that phytoplankton can access $\mathrm{Fe}$ bound to other strong organic ligands in the $\mathrm{L}_{1}$ class. This is reasonable because hydrophilic ferrioxamine siderophores in the ocean are found in only pM concentrations [40, 41] relative to the $\mathrm{nM}$ concentrations of strong Fe binding ligands $\left(\mathrm{L}_{1}\right)$ detected with electrochemical methods. In samples containing both ligand classes $\left(\mathrm{L}_{1}\right.$ and $\left.\mathrm{L}_{2}\right)$, ligand exchange between the weaker $\mathrm{L}_{2}$ ligands and $\mathrm{Fe}$ transporters at the cell surface may facilitate uptake. Indeed, phaeophytin, protoporphyrin IX, and humic acids (log $K_{F e L_{i}, F e^{\prime}}^{c o n d}=11,11.9$, and 11.6, respectively) $[42,43]$ have $\log K_{F e L_{i}, F e^{\prime}}^{c o n d}$ values similar to those in our $\mathrm{L}_{2}$ ligand class, and previous studies have shown that some of these $\mathrm{Fe}$ chelates are more readily available to phytoplankton than FeDFB [18]. Given the elevated oceanic dFe availability compared to FeDFB, we highly recommend incorporating additional strong Fe-binding ligands in uptake experiments.

Our average $\mathrm{dFe}$ bioavailability $\left(\mathrm{k}_{\mathrm{in}-\mathrm{app}} / \mathrm{S}\right.$.A.) is 70 -fold

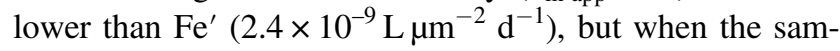
ples were exposed to sunlight, $\mathrm{dFe}$ bioavailability increased by $\sim 6$-fold (Figs. 3 and $4 \mathrm{~b}$ ). Given the higher availability (by 1000 -fold) of $\mathrm{Fe}^{\prime}$ relative to $\mathrm{Fe}$ bound to strong organic ligands, like siderophores [16], we suspect that this enhancement in $\mathrm{dFe}$ bioavailability is due to rapid formation of $\mathrm{Fe}^{\prime}$ in the presence of sunlight, as demonstrated for naturally occurring marine siderophores [44]. The processes at play are probably photoreduction of organically bound $\mathrm{Fe}$ (III) and formation of highly bioavailable inorganic $\mathrm{Fe}$ $[44,45]$. Such photoenhancement of $\mathrm{dFe}$ bioavailability may be very pronounced at low temperatures [46], which retard the oxidation of $\mathrm{Fe}$ (II) to the more insoluble $\mathrm{Fe}$ (III) species [47], thus increasing the steady-state concentration of the dissolved $\mathrm{Fe}^{\prime}$ pool. Photochemistry was also shown to degrade the $\mathrm{L}_{1}$ class ligands [23], and thus may enhance bioavailability by decreasing the competition for inorganic $\mathrm{Fe}$ between free ligand in seawater and ligands-like components involved in phytoplankton Fe uptake mechanisms. A positive effect of light on phytoplankton physiology is less likely, because Fe uptake is not light dependent, and our experiments were short $(1-3 \mathrm{~h})$ relative to the time required to synthesize de-novo proteins by eukaryotic phytoplankton. The data presented here, showing an increase in $\mathrm{dFe}$ availability when samples are exposed to 
sunlight (Figs. 3 and 4), suggest that photochemistry in surface waters plays a significant role in $\mathrm{Fe}$ acquisition from the dissolved organic Fe pool by oceanic phytoplankton, as previously documented [18, 27].

Another factor that can decrease the bioavailability of $\mathrm{dFe}$ is the presence of excess ligands that can compete with the cells for free inorganic $\mathrm{Fe}$ [Fe(II) or $\mathrm{Fe}(\mathrm{III})]$ generated biologically during the uptake processes $[9,11]$ or by photochemical reactions [18, 27]. Such competition occurs if the complexation capacity of the free Fe-binding ligands in seawater $\left(\alpha^{\prime}\right)$ is higher than that of cell-surface ligand-like components of $\mathrm{Fe}$ acquisition mechanisms (herein $\mathrm{Y}$ ). To illustrate this point, we calculated for our experiments the complexation capacity of the free cell-surface associated ligands in $\mathrm{Fe}$ transport, $\alpha_{Y^{\prime}}$ (where $\alpha_{Y^{\prime}}=[Y] \times K_{F e Y, F e^{\prime}}^{c o n d}$ ) and compared it with $\alpha^{\prime}$. For this calculation, we assumed that Fe uptake and speciation are in pseudo-equilibrium (given the low cell densities, low light conditions, and the presence of excess, strong organic Fe-binding ligands), and used published estimates for the diatom $T W$ [12] (see Supplementary Table S7 for details). Our calculated complexation capacity of the free cell-surface associated ligands involved in $\mathrm{Fe}$ transport during our experiments $\left(\alpha_{Y}{ }^{\prime}\right.$, ranged $\left.0.1-1.0\right)$ is orders of magnitude lower than that of the Fe-binding ligands in seawater $\left(\alpha^{\prime}\right.$, ranged 184-1145, Table 1). This implies that in seawater where cell densities are similar and even lower than those in our experiments, free organic ligands may compete effectively for inorganic Fe with ligand-like enzymes or Fe transporters at phytoplankton cell surfaces.

The approach tested and verified in this paper is useful for (a) experimentally probing $\mathrm{dFe}$ availability in natural seawater by using cultured, Fe-limited phytoplankton, (b) predicting dFe bioavailability in oceanic regions, and c) modeling in situ phytoplankton $\mathrm{Fe}$ uptake rates in the ocean. Acknowledging the high complexity of the studied system, comprising multiple organic ligands binding $\mathrm{Fe}$ in seawater (in the $\mathrm{L}_{1}$ and $\mathrm{L}_{2}$ classes), as well as multiple Fe acquisition mechanisms in phytoplankton [11, 20, 48, 49], we postulate that our approach is an important practical solution that can advance our predictive capability of the role of iron in determining phytoplankton growth in the ocean.

For modelers, our rate-constant based approach provides a very simple and direct way to model Fe uptake rates by phytoplankton in ocean water, based on the following equation:

In situ uptake rate $\left(\mathrm{mol} \mu \mathrm{m}^{-2} \mathrm{~d}^{-1}\right)=\mathrm{k}_{\mathrm{in}-\mathrm{app}} / \mathrm{S}$.A. $\left(\mathrm{L} \mu \mathrm{m}^{-2} \mathrm{~d}^{-1}\right)$

$$
\times[\mathrm{SW} \text { dissolved } \mathrm{Fe}]\left(\mathrm{mol} \mathrm{L}^{-1}\right)
$$

where $\mathrm{k}_{\mathrm{in}-\mathrm{app}} / \mathrm{S}$.A. can be modeled as a single averaged

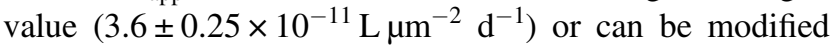
according to photochemistry and temperature. Equation 3 can be extended to include cell numbers or carbon so that in situ uptake rates appear in a more standardized form as uptake rate per cell or algal carbon, respectively. Note that the $\mathrm{k}_{\text {in-app }} / \mathrm{S}$.A. obtained in this study is relevant only under $\mathrm{Fe}$ limitation, when phytoplankton maximize their $\mathrm{Fe}$ transport systems, and cell densities are low. Our study did not include Fe-limited cyanobacteria, which were reported to share similar $\mathrm{k}_{\text {in }} / \mathrm{S}$.A. of $\mathrm{Fe}^{\prime}$ with eukaryotic phytoplankton, but dissimilar $\mathrm{k}_{\text {in }} / \mathrm{S}$.A. of FeDFB or other Fe-siderophore complexes compared to eukaryotic phytoplankton $[16,50]$. Naturally, more research is needed to extend our findings to cyanobacteria, and to fully understand the effect of speciation, photochemistry, and temperature on oceanic $\mathrm{dFe}$ bioavailability.

Currently the parameterization of dFe bioavailability in the biogeochemical model is lacking [51]. Better representation of iron control on phytoplankton growth in models is crucial and timely as it bares implications for the oceanic uptake of atmospheric $\mathrm{CO}_{2}$, nutrient cycles, ocean food webs, and eventually fish catch. The methodology presented here is simple and could assist in evaluating Fe bioavailability in many oceanic locations and under future conditions, including ocean acidification, warming, and deoxygenation. The straightforward approach for modeling in situ Fe uptake by phytoplankton based on $\mathrm{dFe}$ concentrations (Eq. 3) is particularly valuable, given the high-quality and high-resolution $\mathrm{dFe}$ data that are emerging on a global scale from the international GEOTRACES program [52].

Acknowledgements The authors sincerely thank Jingxuan Li and Richard Nixon for seawater collection, Rhiannon Jones for phytoplankton culturing, Eric Achterberg for valuable comments, and Robert Anderson for endless encouragement. We acknowledge the generous funding of the Israel Science Foundation (grant 458/15 to YS), the US National Science Foundation (grants NSF-OCE 1441969 and 1443483 to KB), and the Canadian NSERC grantto MM.; TM was supported in part by a Sanibel-Captiva Shell Club/Mary \& Al Bridell Memorial Fellowship.

\section{Compliance with ethical standards}

Conflict of interest The authors declare that they have no conflict of interest.

Publisher's note Springer Nature remains neutral with regard to jurisdictional claims in published maps and institutional affiliations.

Open Access This article is licensed under a Creative Commons Attribution 4.0 International License, which permits use, sharing, adaptation, distribution and reproduction in any medium or format, as long as you give appropriate credit to the original author(s) and the source, provide a link to the Creative Commons license, and indicate if changes were made. The images or other third party material in this article are included in the article's Creative Commons license, unless indicated otherwise in a credit line to the material. If material is not included in the article's Creative Commons license and your intended use is not permitted by statutory regulation or exceeds the permitted use, you will need to obtain permission directly from the copyright holder. To view a copy of this license, visit http://creativecommons. org/licenses/by/4.0/. 


\section{References}

1. de Baar HJW, Boyd PW, Coale KH, Landry MR, Tsuda A, Assmy P, et al. Synthesis of iron fertilization experiments: from the iron age in the age of enlightenment. J Geophys Res-Oceans. 2005; 110:1-24

2. Berman-Frank I, Cullen JT, Shaked Y, Sherrell RM, Falkowski PG. Iron availability, cellular iron quotas, and nitrogen fixation in Trichodesmium. Limnol Oceanogr. 2001;46:1249-60.

3. Martin JH, Coale KH, Johnson KS, Fitzwater SE, Gordon RM, Tanner SJ, et al. Testing the iron hypothesis in ecosystems of the equatorial Pacific Ocean. Nature. 1994;371:123-9.

4. Kolber ZS, Barber RT, Coale KH, Fitzwater SE, Greene RM, Johnson KS, et al. Iron limitation of phytoplankton photosynthesis in the equatorial Pacific Ocean. Nature. 1994;371:145-9.

5. Tagliabue A, Bowie AR, Boyd PW, Buck KN, Johnson KS, Saito MA. The integral role of iron in ocean biogeochemistry. Nature. 2017;543:51-9.

6. Boyd PW, Watson AJ, Law CS, Abraham ER, Trull T, Murdoch R, et al. A mesoscale phytoplankton bloom in the polar Southern Ocean stimulated by iron fertilization. Nature. 2000;40:695-702.

7. Brand LE. Minimum iron requirements of marine phytoplankton and the implications for biogeochemical control of new production. Limnol Oceanogr. 1991;36:1756-72.

8. Sunda WG, Huntsman SA. Processes regulating cellular metal accumulation and physiological effects: phytoplankton as model system. Sci Total Environ. 1998;219:165-81.

9. Shaked Y, Kustka AB, Morel FMM. A general kinetic model for iron acquisition by eukaryotic phytoplankton. Limnol Oceanogr. 2005;50:872-82.

10. Morel FMM, Rueter JG, Price NM. Iron nutrition of phytoplankton and its possible importance in the ecology of ocean regions with high nutrient and low biomass. Oceanography. 1991;4:56-61.

11. Maldonado MT, Price NM. Reduction and transport of organically bound iron by Thalassiosira oceanica (Bacillariophyceae). J Phycol. 2001;37:298-309.

12. Hudson RJ, Morel FMM. lron transport in marine phytoplankton: kinetics of cellular and medium coordination reactions. Limnol Oceanogr. 1990;35:1002-20.

13. Hudson RJ, Morel FMM. Trace metal transport by marine microorganisms: implications of metal coordination kinetics. Deep Res. 1993;40:129-50.

14. Sunda WG, Huntsman SA. Iron uptake and growth limitation in oceanic and coastal phytoplankton. Mar Chem. 1995;50: 189-206.

15. Sunda WG, Swift DG, Huntsman SA. Low iron requirement for growth in oceanic phytoplankton. Nature. 1991;351:55-7.

16. Lis H, Shaked Y, Kranzler C, Keren N, Morel FMM. Iron bioavailability to phytopalnkton: an emperical approach. ISME J. 2015;9:1003-13.

17. Morel FMM, Kustka AB, Shaked Y. The role of unchelated Fe in the iron nutrition of phytoplankton. Limnol Oceanogr. 2008; 53:400-4.

18. Maldonado MT, Strzepek RF, Sander S, Boyd PW. Acquisition of iron bound to strong organic complexes, with different Fe binding groups and photochemical reactivities, by plankton communities in Fe-limited subantarctic waters. Global Biogeochem Cycles. 2005;19:GB4S23.

19. Shaked Y, Lis H. Disassembling iron availability to phytoplankton. Front Microbiol. 2012;3:Article 123.

20. Maldonado MT, Allen AE, Chong JS, Dan Leus KL, Karpenko N, Harris SL, et al. Copper-dependent iron transport in coastal and oceanic diatoms. Limnol Oceanogr. 2006;51:1729-43.
21. Marchetti A, Maldonado M, Iron. In: Borowitzka MA, Beardall J, Raven JA, editors. The physiology of microalgae. Springer; 2016. p. 233-79.

22. Buck KN, Sohst B, Sedwick PN. The organic complexation of dissolved iron along the U.S. GEOTRACES (GA03) North Atlantic Section. Deep Res Part II Top Stud Oceanogr. 2015; 116:152-65.

23. Bundy RM, Jiang M, Carter M, Barbeau KA. Iron-binding ligands in the southern california current system: mechanistic studies. Front Mar Sci. 2016;3:Article 27.

24. Gledhill M, Buck KN. The organic complexation of iron in the marine environment: a review. Front Microbiol. 2012;3: Article 69.

25. Cutter G, Andersson P, Codispoti L, Croot P, Place P, Hoe T, et al. Sampling and sample-handling protocols for GEOTRACES cruises, version 3.0 ed. 2017: p. 1-178.

26. Buck KN, Moffett J, Barbeau KA, Bundy RM, Kondo Y, Wu J. The organic complexation of iron and copper: An intercomparison of competitive ligand exchange-adsorptive cathodic stripping voltammetry (CLE-ACSV) techniques. Limnol Oceanogr Methods. 2012;10:496-515.

27. Mellett T, Brown MT, Chappell PD, Duckham C, Fitzsimmons JN, Till CP, et al. The biogeochemical cycling of iron, copper, nickel, cadmium, manganese, cobalt, lead, and scandium in a California current experimental study. Limnol Oceanogr. 2018;63: S425-47.

28. Hudson RJM, Morel FMM. Distinguishing between extra- and intracellular iron in marine phytoplankton. Limnol Oceanogr. 1989;34:1113-20.

29. Buck KN, Sedwick PN, Sohst B, Carlson CA. Organic complexation of iron in the eastern tropical South Pacific: results from US GEOTRACES Eastern Pacific Zonal Transect (GEOTRACES cruise GP16). Mar Chem. 2018;201:229-41.

30. Omanović D, Garnier C, Pižeta I. ProMCC: An all-in-one tool for trace metal complexation studies. Mar Chem. 2015;173:25-39.

31. Pižeta I, Sander SG, Hudson RJM, Omanović D, Baars O, Barbeau KA, et al. Interpretation of complexometric titration data: an intercomparison of methods for estimating models of trace metal complexation by natural organic ligands. Mar Chem. 2015; 173:3-24.

32. Croot PL, Heller MI. The importance of kinetics and redox in the biogeochemical cycling of iron in the surface ocean. Front Microbiol. 2012;3:Article 219.

33. Shi D, Xu Y, Hopkinson BM, Morel FMM. Effect of ocean acidification on iron availability to marine phytoplankton. Science.2010;327:676-9.

34. Mies KA, Wirgau JI, Crumbliss AL. Ternary complex formation facilitates a redox mechanism for iron release from a siderophore. BioMetals. 2006;19:115-26.

35. Harrington JM, Crumbliss AL. The redox hypothesis in siderophore-mediated iron uptake. Biometals. 2009;22:679-89.

36. Croot PL, Bowie AR, Frew RD, Maldonado MT, Hall JA, Safi $\mathrm{KA}$, et al. Retention of dissolved iron and Fe-II in an iron induced Southern Ocean phytoplankton bloom. Geophys Res Lett. 2001;28:3425-8.

37. Hassler CS, Schoemann V. Bioavailability of organically bound $\mathrm{Fe}$ to model phytoplankton of the Southern Ocean. Biogeosciences. 2009;6:2281-96.

38. Sunda WG, Huntaman SA. Interrelated influence of iron, light and cell size on marine phytoplankton growth. Nature. 1997;390: 389-92.

39. Rue EL, Bruland KW. Complexation of iron(III) by natural organic ligands in the central North Pacific as determined by a new competitive ligand equilibration/adsorptive cathodic stripping voltammetric method. Mar Chem. 1995;50:117-38. 
40. Mawji E, Gledhill M, Milton JA, Tarran GA, Ussher S, Thompson A, et al. Hydroxamate siderophores: Occurrence and importance in the Atlantic Ocean. Environ Sci Technol. 2008;42:8675-80.

41. Boiteau RM, Mende DR, Hawco NJ, McIlvin MR, Fitzsimmons JN, Saito MA, et al. Siderophore-based microbial adaptations to iron scarcity across the eastern Pacific Ocean. Proc Natl Acad Sci. 2016;113:14237-42.

42. Luther GW, Rozan TF, Witter A, Lewis B. Metal-organic complexation in the marine environment. Geochem Trans. 2001; 2:65-74.

43. Abualhaija MM, van den Berg CMG. Chemical speciation of iron in seawater using catalytic cathodic stripping voltammetry with ligand competition against salicylaldoxime. Mar Chem. 2014; 164:60-74.

44. Barbeau K, Rue EL, Bruland KW, Butler A. Photochemical cycling of iron in the surface ocean mediated by microbial iron (III)-binding ligands. Nature. 2001;413:409-13.

45. Barbeau K, Rue EL, Trick CG, Bruland KT, Butler A. Photochemical reactivity of siderophores produced by marine heterotrophic bacteria and cyanobacteria based on characteristic Fe(III) binding groups. Limnol Oceanogr. 2003;48:1069-78.
46. Croot PL, Bluhm K, Schlosser C, Streu P, Breitbarth E, Frew R, et al. Regeneration of Fe(II) during EIFeX and SOFeX. Geophys Res Lett. 2008;35:L19606.

47. Millero FJ, Sotolongo S, Izaguirre M. The oxidation kinetics of Fe (II) in seawater. Geochim Cosmoshimica Acta. 1987;51:793-801.

48. Morrissey J, Bowler C. Iron utilization in marine cyanobacteria and eukaryotic algae. Front Microbiol. 2012;3:Article 43.

49. McQuaid JB, Kustka AB, Oborník M, Horák A, McCrow JP, Karas BJ, et al. Carbonate-sensitive phytotransferrin controls high-affinity iron uptake in diatoms. Nature. 2018;555:534-7.

50. Lis H, Kranzler C, Keren N, Shaked Y. A comparative study of Iron uptake rates and mechanisms amongst marine and fresh water Cyanobacteria: prevalence of reductive Iron uptake. Life. 2015;5:841-60.

51. Tagliabue A, Aumont O, Death R, Dunne JP, Dutkiewicz S, Galbraith E, et al. How well do global ocean biogeochemistry models simulate dissolved iron distributions? Glob Biogeochem Cycles. 2016;30:149-74.

52. Anderson RF GEOTRACES: accelerating research on the marine biogeochemical cycles of trace elements and their isotopes. Ann Rev Mar Sci. 2019;12:1-37. 